\title{
The roles of glutamate dehydrogenase, glutamine synthetase and three forms of glutamate synthase in nitrogen assimilation in various organs of Pisum arvense $\mathrm{L}$.
}

GENOWEFA KUBIK-DOBOSZ

Department of Plant Physiology, Institute of Botany, University of Wrocław, Kanonia 6/8, 50-328 Wrocław, Poland

(Received: February 28, 1990. Accepted: May 22, 1990)

\begin{abstract}
The activities of GDH, GS and three forms of GOGAT (NADH, NADPH or ferredoxin-dependent) were studied in the leaves, stems and roots of the Pisum arvense. GS and the individual forms of GOGAT dominated in the leaves of 7 day-old plants which were taking up $\mathrm{NO}_{3}{ }^{-}$or $\mathrm{NH}_{4}{ }^{+}$ions, while NADH-GDH dominated in the roots of these plants. In comparison with $\mathrm{HNO}_{3}^{-}, \mathrm{NH}_{4}{ }^{+}$ions stimulated the activity of most of the enzymes of the GS/GOGAT and GDH pathways in stems and roots, while in and leaves this effect was age-dependent. The Fd-GOGAT located in leaves and stems was not regulated by $\mathrm{NH}_{4}{ }^{+}$, which indicates that this enzyme is not likely to be directly involved in the assimilation of $\mathrm{NH}_{4}{ }^{+}$ions that have been taken up. The obtained data indicate that at lower tissue $\mathrm{NH}_{4}{ }^{+}$ concentration a decisive role in nitrogen assimilation in leaves and stems is played by the GS/GOGAT pathway, while in the roots - by GDH and in less degree by GS/GOGAT. High amounts of accumulated $\mathrm{NH}_{4}{ }^{+}$ions set off a detoxication mechanism which includes NADH-GDH, common to all tissues. Only in 7 day-old leaves did the detoxication of $\mathrm{NH}_{4}{ }^{+}$ take place with the involvement of NADH-GOGAT and NADPH-GOGAT.
\end{abstract}

Key words: assimilation of $\mathrm{NH}_{4}^{+}$, glutamate dehydrogenese, glutamine synthetase, glutamate synthase

\section{INTRODUCTION}

The assimilation of ammonium ions in the tissues of higher plants may occur via the GS/GOGAT or GDH pathways. The low Km of glutamine synthetase for $\mathrm{NH}_{4}{ }^{+}$, which equals approximately $20 \mu \mathrm{M}$ (M i fl i n and L e a 1967) suggested that this enzyme is, along with glutamate synthase, the main route of $\mathrm{NH}_{4}{ }^{+}$ assimilation. The role of glutamate dehydrogenase in this process was questioned (Proby n and Lew is 1979, R hodes et al. 1980) because of its low affinity for $\mathrm{NH}_{4}{ }^{+}\left(\mathrm{Km} \mathrm{GDH}\right.$ for $\mathrm{NH}_{4}{ }^{+}$is approx. 10-50 mM, M i fl i $\mathrm{n}$ and $\mathrm{Le}$ a 1977). The studies of $\mathrm{Pa} \mathrm{h} \mathrm{l} \mathrm{i} \mathrm{c} \mathrm{h} \mathrm{and} \mathrm{G} \mathrm{e} \mathrm{r} \mathrm{li} \mathrm{t} \mathrm{z} \mathrm{(1980)} \mathrm{and} \mathrm{M} \mathrm{a} \mathrm{z} \mathrm{u} \mathrm{r} \mathrm{o} \mathrm{w} \mathrm{a} \mathrm{(1986)} \mathrm{carried}$ 
out on purified pea and lupine enzymes have shown that GDH may adapt itself to low $\mathrm{NH}_{4}{ }^{+}$concentrations and thus fulfil an assimilatory role in the binding of ammonium ions ( $\mathrm{Singh}$ and S riva stava 1982, B ielawski and K ąc kowski 1984, Loyola-Vargas and Sanches de Jimenez 1984, $\mathrm{Ze} \mathrm{l} \mathrm{mer}$ and $\mathrm{G} u \mathrm{n}$ ther 1988). Its seems that the level of the substrate in plant tissues may be the factor determining the participation of the GS/GOGAT and GDH pathways in the assimilation of the ammonium ions taken up.

In the study presented here the participation of various enzymes of the GS/GOGAT and GDH pathways in the assimilation of $\mathrm{NH}_{4}{ }^{+}$taken up by plants from the culture medium or arising from the reduction of nitrates in leaves, stems and roots of the Pisum arvense was studied.

\section{MATERIAL AND METHODS}

Pea (Pisum arvense L. var. Nieznaniecki) seeds were germinated for 2 days at $27^{\circ} \mathrm{C}$ in the dark. The seedlings were then transferred to a nitrate (in $\mathrm{mM}$ : $5 \mathrm{Ca}\left(\mathrm{NO}_{3}\right)_{2}, 5 \mathrm{KNO}_{3}, 1 \mathrm{KH}_{2} \mathrm{PO}_{4}, 1 \mathrm{MgSO}_{4}$ ) or ammonium medium (in mM: 15 $\left.\mathrm{NH}_{4} \mathrm{Cl}, 5 \mathrm{CaSO}_{4}, 1 \mathrm{KH}_{2} \mathrm{PO}_{4}, 2.5 \mathrm{~K}_{2} \mathrm{SO}_{4}, 1 \mathrm{MgSO}_{4}\right)$. The mediums contained microelements as described previously (K u bi k - D obos z 1989). Fresh medium was supplied every two days. The plants were grown in 17 hours of light $\left(15.5 \mathrm{~W} . \mathrm{m}^{-2}\right)$ and 7 hours of darkness. The leaves, stems and roots of 7 and 14 day-old plants were used for analysis. The plant material was homogenized in a mortar using $2 \mathrm{~cm}^{3}$ of $50 \mathrm{mM} \mathrm{KH_{2 }} \mathrm{PO}_{4}-\mathrm{KOH}$ pH 7.5, $1 \mathrm{mM}$ EDTA, $10 \mathrm{mM}$ $\mathrm{MgCl}_{2}$ and $2 \mathrm{mM}$ dithiothreitol per gram of material. The homogenate was filtered through four layers of gauze and centrifuged $15 \mathrm{~min}$. at $21000 \times \mathrm{g}$. The activities of GS, NADH-GDH, NADH-GOGAT, NADPH-GOGAT and Fd-GOGAT were determined in the supernatant.

The activity of GS was assayed using the transferase method of $\mathrm{H} \mathrm{i} \mathrm{p} \mathrm{k} \mathrm{i} \mathrm{n}$ and $\mathrm{S}$ y r r e t (1977) in a reaction medium containing tris- $\mathrm{HCl}(0.05 \mathrm{M} \mathrm{pH} 7.2)$, ADP $(1 \mathrm{mM})$, glutamine $(47 \mathrm{mM})$, sodium arsenate $(20 \mu \mathrm{M})$ and hydroxylamine $(13$ $\mathrm{mM}$ ). The activities of NADH-GOGAT, NADPH-GOGAT and Fd-GOGAT were determined according to $\mathrm{M}$ a t o $\mathrm{ch}$ and $\mathrm{T}$ a $\mathrm{k}$ a h a s h $\mathrm{i}(1982)$ in the presence of $50 \mathrm{mM} \mathrm{KH}_{2} \mathrm{PO}_{4}-\mathrm{KOH} \mathrm{pH} 7.5,10 \mathrm{mM}$ 2-oxoglutarate, $10 \mathrm{mM}$ glutamine and, appropriately, $0.6 \mathrm{mM} \mathrm{NAD} / \mathrm{P} / \mathrm{H}$ or $0.23 \mathrm{mg}$ ferredoxin and $12 \mathrm{mM} \mathrm{Na}_{2} \mathrm{~S}_{2} \mathrm{O}_{4}$ and $13.5 \mathrm{mM} \mathrm{NaHCO}$. After stopping the reaction by immersing in a boiling water bath for $1 \mathrm{~min}$. the samples were centrifuged $10 \mathrm{~min}$ at $10000 \times \mathrm{g}$. The supernatant was applied to a column packed with Dowex $1 \times 8$. And glutamic acid was eluted and then assayed by the ninhydrin method (M a t o h et al. 1979, 1980). The activity of NADH-GDH was analyzed according to D u ke et al. (1975) in the presence of $0.33 \mathrm{M}$ 2-oxoglutarate, $3 \mathrm{M} \mathrm{NH}_{4} \mathrm{Cl}, 3 \mathrm{mM} \mathrm{NADH}, 0.1 \mathrm{M}$ tris- $\mathrm{HCl} \mathrm{pH} \mathrm{8.0.} \mathrm{The} \mathrm{NH}_{4}{ }^{+}$ion content was determined according to the method of M c C u 11 o u g h (1967) after staining an aqueous extract of the plant material with the phenol-hypochlorite reagent. 
The presented results are the means of three independent experiments. The data obtained in the individual experiments all showed the same type of changes.

\section{RESULTS}

As can be seen from Fig. 1, the activity of GS dominated in leaves, regardless of the age of the plants ( 7 or 14 days) and the form of nitrogen taken up $\left(\mathrm{NO}_{3}^{-}\right.$, $\left.\mathrm{NH}_{4}{ }^{+}\right)$. The activity of GS was very low in the stems and roots and did no usually exceed $20 \%$ of GS activity in leaves. In the presence of $\mathrm{NH}_{4}{ }^{+}$increases by $27-74 \%$ in GS activity were seen in most of the organs of all of the plants.

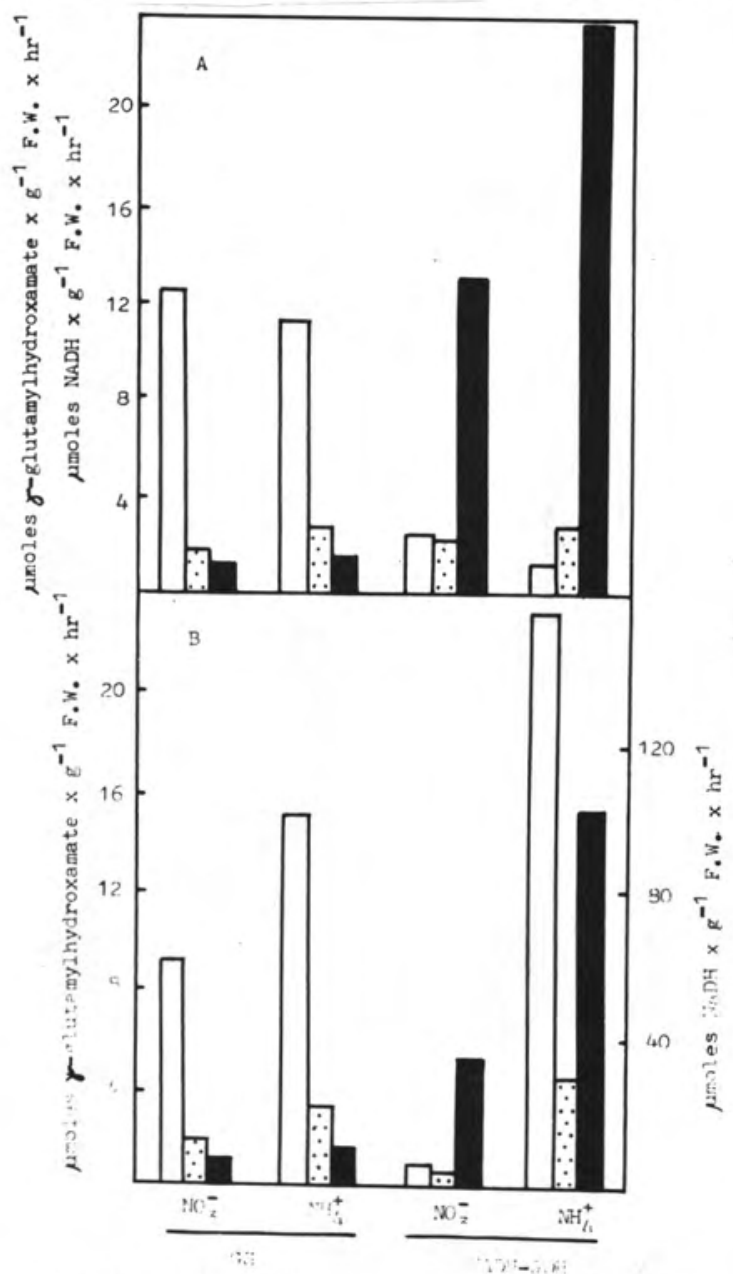

Fig. 1. The activity of GS and NADH-GDH in leaves, stems and roots of Pisum arvense. The plants were grown for 7 days (A) or 14 days (B) in a nitrate $\left(\mathrm{NO}_{3}^{-}\right)$or ammonium $\left(\mathrm{NH}_{4}{ }^{+}\right)$medium. The activity of the enzyme was measured in leaves (light bars), stems (dotted bars) and roots (dark bars) 
The data contained in Fig. 1A suggest that NADH-GDH was most active in the roots of plants from both $\mathrm{NO}_{3}{ }^{-}$and $\mathrm{NH}_{4}{ }^{+}$mediums and that it showed negligible activity in leaves and stems. However, after 14 days, the activity of $\mathrm{NADH}-\mathrm{GDH}$ in the leaves of plants growing in the presence of $\mathrm{NH}_{4}{ }^{+}$rose dramatically (Fig. 1B). A similar, although, somewhat smaller effect related to ammonium ions was also observed in the stems and roots of 14 day-old plants.

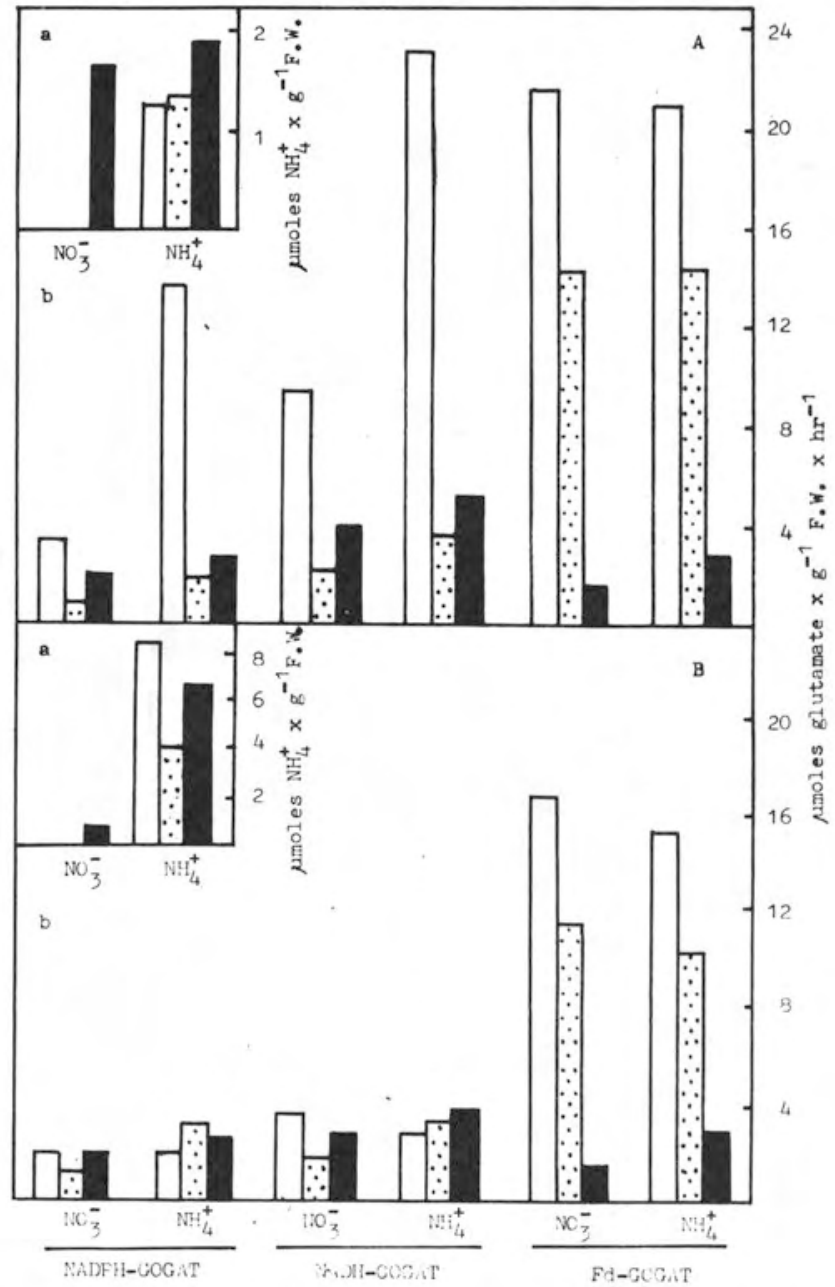

Fig. 2. The $\mathrm{NH}_{4}{ }^{+}$content (a) and activity of NADPH-GOGAT, NADH-GOGAT and Fd-GOGAT (b) in leaves, stems and roots of $P$. arvense. Remaining legend as in Fig. 1

The leaves and stems of all of the studied plants were characterized by a high Fd-GOGAT activity, whereas in the roots the activity of this enzyme was low (Fig. 2). In comparison with the $\mathrm{N}-\mathrm{NO}_{3}{ }^{-}$combination, the ammonium nitrogen increased the activity of Fd-GOGAT in the roots but did not cause a change in 
the activity of this enzyme in the remaining organs. The results presented on Fig. $2 \mathrm{~A}$ also indicate that after 7 days of growth of the plants, $\mathrm{NH}_{4}{ }^{+}$ions increased the activities of NADH-GOGAT and NADPH-GOGAT in all of the organs, especially in the leaves. However, after 14 days the activities of NADH-GOGAT and NADPH-GOGAT in leaves, stems and roots remained on a similarly low level (Fig. 2B) in spite of the fact that $\mathrm{NH}_{4}{ }^{+}$ions stimulated the activity of both of these enzymes in the stems by $100-138 \%$.

Regardless of the form of nitrogen in the medium, the roots of 7 day-old plants accumulated similar amounts of $\mathrm{NH}_{4}{ }^{+}$ions (Fig. 2A). In the plants from the $\mathrm{NO}_{3}{ }^{-}$combination, ammonium ions were not found in stems and leaves. However, in the plants growing in the ammonium medium, $\mathrm{NH}_{4}{ }^{+}$ions were also found in leaves and stems and their amount increased during cultivation. The highest amounts of free ammonium ions accumulated in the leaves of 14 day-old plants from the $\mathrm{NH}_{4}{ }^{+}$combination (Fig. 2B).

Methionine sulfoximine (MSO) - a specific inhibitor of GS - blocks the assimilation of $\mathrm{NH}_{4}{ }^{+}$in the GS/GOGAT pathway. If plants from the nitrate or ammonium mediums were treated with this inhibitor for 24 hours, then high amounts of ammonium ions were detected in the stems and leawes of such plants, reaching values of 5.3-26.8 $\mu$ moles $/ \mathrm{g}$ fresh weight (Table 1). The increase in the level of $\mathrm{NH}_{4}{ }^{+}$in response to MSO in the roots was small and did no exceed 1.1-1.8 $\mu$ moles/g fresh weight.

\section{Table 1}

The effect of methionine sulfoximine (MSO) on the $\mathrm{NH}_{4}{ }^{+}$ion content $\left(\mu\right.$ moles $\mathrm{NH}_{4}{ }^{+} \mathrm{x} \mathrm{g}^{-1}$ fr.w) in leaves, stems and roots of Pisum arvense

\begin{tabular}{|l|r|r|c|}
\hline \multicolumn{1}{|c|}{ Treatment } & Leaves & Stems & Roots \\
\hline $\mathrm{NO}_{3}{ }^{-}$ & 0.0 & 0.0 & 2.0 \\
$\mathrm{NO}_{3}{ }^{-}+$MSO & 23.0 & 5.3 & 3.8 \\
$\mathrm{NH}_{4}{ }^{+}$ & 2.9 & 1.9 & 3.6 \\
$\mathrm{NH}_{4}{ }^{+}+$MSO & 26.8 & 19.6 & 4.7 \\
\hline
\end{tabular}

The plants were grown for 5 days in nitrate $\left(\mathrm{NO}_{4}{ }^{-}\right)$or ammonium $\left(\mathrm{NH}_{4}{ }^{+}\right)$medium, and then for 24 hours with $2.5 \mathrm{mM}$ MSO added to the mediums.
Table 2

The effect of methionine sulfoximine (MSO) on the activity of NADH-GDH $\left(\mu\right.$ moles NADH x g ${ }^{-1}$ fr. w. $\mathrm{x} \mathrm{h}^{-1}$ )

\begin{tabular}{|l|l|l|l|}
\hline \multicolumn{1}{|c|}{ Treatment } & Leaves & \multicolumn{1}{c|}{ Stems } & Roots \\
\hline $\mathrm{NH}_{4}{ }^{+}$ & 1.0 & 1.4 & 25.3 \\
$\mathrm{NH}_{4}{ }^{+}+$MSO & $1.1^{\prime}(110)$ & $0.9(64)$ & $19.3(76)$ \\
\hline
\end{tabular}

The plants were grown for 5 days in an ammonium $\left(\mathrm{NH}_{4}{ }^{+}\right)$medium, and then for 24 hours in the presence of $2.5 \mathrm{mM}$ MSO. The values in parentheses show percent of control.

As can be seen from the data presented in Table 2, MSO caused a drop in the activity of NADH-GDH in the stems and roots, whereas it did not affect the level of activity of this enzyme in the leaves.

\section{DISCUSSION}

Although there is sufficient evidence that there are two metabolic pathways (GS/GOGAT and GDH) incorporating $\mathrm{NH}_{4}{ }^{+}$into amino acids in plant tissues 
(M if 1 i n and Le a 1976), the role of the individual enzymes of both pathways in the assimilation of ammonium ions in the various tissues is still insufficiently documented. The matter is further complicated by the fact that some of the enzymes, such as glutamate synthase, may occur in several molecular forms to which various physiological roles are attributed. Marquez et al. (1986) suggest that Fd-GOGAT is responsible for the photosynthetic and photorespiratory assimilation of ammonium and that NADH-GOGAT assimilates $\mathrm{NH}_{4}{ }^{+}$ arising from the reduction of nitrates or from the metabolism of organic nitrogen compounds. In contrast with the data obtained for other species of plants (A rima 1978, Stewart and Rhodes 1978, Bielawski and Kączk ow s k i 1984), we found all of the enzymes of the GS/GOGAT and GDH pathways in the above-ground and underground parts of Pisum arvense. However, the activities of these enzymes were significantly dependent on the organ and age of the plant. Similarly as in barley or rye seedlings (L e w is et al. 1982, B i e la wo s k i and K ą c z k ow s k i 1984), NADH-GDH had the highest activity in the roots of $P$. arvense. Significant amounts of ammonium ions taken up directly from the medium or arising from the reduction of nitrates were found in these organs. $P$. arvense roots seem to be well adapted to the binding of $\mathrm{NH}_{4}{ }^{+}$ in the NADH-GDH pathway, while the GS/GOGAT pathway is not so important here. In leaves and stems the GS/GOGAT system seems to be preferred. The NAD-GDH activity in roots of 7 and 14 days-old plants was very slight stimulated by $\mathrm{NH}_{4}{ }^{+}$ions (data not presented).

The experiments conducted with MSO have supplied additional evidence confirming the role played by the GS/GOGAT pathway in the assimilation of ammonium ions in the stems and leaves of $P$. arvense and of GDH in the roots. This inhibitor effectively inhibits GS (M a r t i n et al. 1983), blocking the binding if $\mathrm{NH}_{4}{ }^{+}$in the GS/GOGAT pathway. As is seen from Table 1, the intense acumulation of $\mathrm{NH}_{4}{ }^{+}$under the influence of MSO took place only in the leaves and stems. A rise in the amount of accumulated $\mathrm{NH}_{4}{ }^{+}$in the roots of MSO-treated plants was only from $30-90 \%$, which corresponds roughly to the fall in NADH-GDH activity in these organs (Table 2).

Under conditions of a high supply of $\mathrm{NH}_{4}{ }^{+}$from the medium, $P$. arvense tissues began to put to use a mechanism detoxicating the excess ions. In the roots, this mechanism encompassed mainly NADH-GDH, which agrees with the data presented earlier in a paper by $\mathrm{G}$ i v a $\mathrm{n}$ (1979). However, in the leaves and stems of 7 day-old plants which were taking up $\mathrm{NH}_{4}{ }^{+}$, strong stimulation of NADH-GOGAT and NADPH-GOGAT was observed while at the same time the activity of NADH-GDH remained unchanged. The physiological role of NADH-GOGAT decreased however with the age of the plants, leading to a change in the proportions of NADH-GOGAT to Fd-GOGAT in the developing leaves. M a to h and $\mathrm{T} \mathrm{a} \mathrm{k} \mathrm{a} \mathrm{h} \mathrm{a} \mathrm{s} \mathrm{h} \mathrm{i} \mathrm{(1982)} \mathrm{suspect} \mathrm{that} \mathrm{this} \mathrm{change}$ results from developmental changes in plastids and a correlation between light-processes and the activity of Fd-GOGAT. The rapid detoxication of the 
ammonium ions accumulated in the leaves and stems of 14 day-old plants in the $\mathrm{NH}_{4}{ }^{+}$combination was made possible by NADH-GDH, whose activity rose abruptly. The $\mathrm{NH}_{4}{ }^{+}$ions did not, however, affect the activity of Fd-GOGAT located in leaves and stems of $P$. arvense. As can be seen from studies (B o t e 11 a et al. 1988), almost all of the Fd-GOGAT activity in photosynthesizing tissues is associated with chloroplasts. The data presented in the paper by O g r e n (1984) show that this enzyme is necessary for the assimilation of the $\mathrm{NH}_{4}{ }^{+}$released during photorespiration. We suggest that the role of leaf Fd-GOGAT in the assimilation of ammonium ions taken up from an external solution is insignificant.

\section{Acknowledgment}

This study was financed through problem CPBP 05.02 .

\section{REFERENCES}

A rima Y., 1978. Glutamate synthase in rice root extracts and the relationship among electron donors, nitrogen donors and its activity. Plant Cell Physiol. 19: 955-961.

B i e lawski N., K ą czk owski J., 1984. Pathways of ammonia assimilation in rye seedlings at different concentration of $\mathrm{NH}_{4}{ }^{+}$. I. The enzyme activities and level of metabolites. Acta Physiol. Plant. 6: 145-158.

B ot ella J.R., Verbele n J.P., V a l puest a V., 1988. Immunocytolocalization of ferredoxin-GOGAT in the cells of green leaves and cotyledons of Lycopersicon esculentum. Plant Physiol. 87: 255-257.

D u k e S.H., K o u k k a r i W.L., S o u le n T.K., 1975. Glutamate dehydrogenase activity in roots: distribution in a seedling and storage root and the effects of red and far-red illuminations. Physiol. Plant. 34: 8-13.

G i v a n C.V., 1979. Metabolic detoxification of ammonia in tissues of higher plants. Phytochemistry 18: $375-382$.

H i p k in C.R., S y r r e t P.J., 1977. Some effects of nitrogen-starvation on nitrogen and carbohydrate metabolism in Ankistrodesmus braunii. Planta 133: 209-214.

K ubik-Dobosz G., 1989. The activity od NADH-, NADPH- and Fd-dependent glutamate synthease in the plastids and cytosol of Pisum arvense L. root. Acta Soc. Bot. Pol. 58: 253-261.

Lew is O.A.M., J a me s D.M., Hewit t E.J., 1982. Nitrogen assimilation in barley (Hordeum vulgare L. c.v. Mazurka) in response to nitrate and ammonium nutrition. Ann. Bot. 49: 39-49.

Loyola-Vargas V.M., Sanchez de Jimenez E., 1984. Differential role of glutamate dehydrogenase in nitrogen metabolism of maize tissues. Plant Physiol. 76: 536-540.

M a r q u e z A.J., G a I v a F., V e g a J.M., 1986. Utilization of ammonium by mutant and wilde types of Chlamydomonas reinhardii. Studies of the glutamate synthase activities. J. Plant Physiol. 124: 95-102.

Martin F., Winspear M.J., M a c Farlane J.D., Oaks A., 1983. Effect of methionine sulfoximine on the accumulation of ammonia in $\mathrm{C}_{3}$ and $\mathrm{C}_{4}$ leaves. Plant Physiol. 71: 177-181.

M a t o h T., I d a S., T a k a h a s h i E., 1980. A rapid and sensitive assay for ferredoxin glutamate synthase. Bull. Res. Inst. Food Sci. Kyoto Univ. 43: 1-6.

M a to h T., T a k a h a s h i E., 1982. Changes in the activities of ferredoxin- and NADH-glutamate synthase during seedling development of peas. Planta 154: 289-294. 
Matoh T., Takahashi E., I d a S., 1979. Glutamate synthase in developing pea cotyledons: occurence of NADH-dependent and ferredoxin-dependent enzymes. Plant Cell Physiol. 20: 1455-1459.

Mazurowa H., 1986. Powiązania torów metabolicznych procesów oddychania i przyswajania azotu w roślinach motylkowatych. Univ. A. Mickiewicz in Poznań. Ser. Biol. No 31: 1-104.

M c Cullough H., 1967. The determination of ammonia in whole blood by direct colorimetric method. Clin. Chim. Acta 17: 297-304.

M ifli in B.J., Le a P.J., 1976. The pathway of nitrogen assimilation in plants. Phytochemistry 15: 873-885.

M iflin B.J., Le a P.J., 1977. Amino acid metabolism. Ann. Rev. Plant Physiol. 28: 299-329.

Ogren W. L., 1984. Photorespiration: pathways, regulation and modification. Ann. Rev. Plant Physiol. 35: 415-422.

Pahlich E., Gerlitz Chr., 1980. Deviations from Michaelis-Menten behavior of plant glutamate dehydrogenase with ammonium as variable substrate. Phytochemistry 19: 11-13.

Probyn T.A., Lewis O.A.M., 1979. The route of nitrate-nitrogen assimilation in the root of Datura stramonium L. J. Exp. Bot. 30: 299-305.

R hodes D., S i m s A.P., Folkes B.F., 1980. Pathway of ammonia assimillation in illuminated Lemna minor. Phytochemistry 19: 357-366.

Sing h R.P., S rivast a va H.S., 1982. Glutamate dehydrogenase activity and assimilation of inorganic nitrogen in maize seedlings. Biochem. Physiol. Pflanzen 177: 633-642.

S tew a r t G.R., R h od e s D., 1978. Nitrogen metabolism of halophyles. III. Inzymes of ammonia assimilation. New Phytol. 80: 307-316.

Zelmer I., Gunther G., 1988. Activities of glutamate dehydrogenase (GDHI), glutamine synthetase (GS) and glutamate synthase (GOGAT) in suspension cultures of Beta vulgaris (sugar beet) and Chenopodium album (Goosefoot). Biochem. Physiol. Pflanzen 1\$3: 397-405.

Udzial dehydrogenazy glutaminianowej, syntetazy glutaminowej i trzech form yntazy glutaminianowej w asymilacji azotu w różnych organach Pisum arvense L.

\section{Streszczenie}

Badano aktywność GDH, GS i trzech form GOGAT (zależnej od NADH, NADPH lub ferredoksyny) w liściach, lodygach i korzeniach grochu polnego (Pisum arvense). W liściach 7-dniowych roślin pobierających jony $\mathrm{NO}_{3}^{-}$lub $\mathrm{NH}_{4}^{+}$dominowała GS i poszczególne rodzajc GOGAT, natomiast w korzeniach - NADH-GDH. W stosunku do $\mathrm{NO}_{3}{ }^{-}$, jony $\mathrm{NH}_{4}{ }^{\prime}$ stymulowaly aktywność większości enzymów szlaków GS/GOGAT i GDH w łodygach i korzeniach, natomiast w liściach efekt zależał od wieku roślin. Fd-GOGAT zlokalizowana w liściach i łodygach nie byla regulowana przez $\mathrm{NH}_{4}{ }^{+}$co wskazuje, że ten enzym raczej nie uczestniczy bezpośrednio w asymilacji pobranych jonów $\mathrm{NH}_{4}{ }^{+}$. Jak wynika $\mathrm{z}$ uzyskanych danych, przy mniejszej zawartości $\mathrm{NH}_{4}{ }^{\text {}}$ w tkankach, decydującą rolę w asymilacji azotu w liściach i łodygach odgrywa szlak GS/GOGAT, natomiast w korzeniach głównie GDH i w mniejszym stopniu GS/GOGAT. Duże ilości zakumulowanych jonów $\mathrm{NH}_{4}{ }^{+}$uruchamiają wspólny dla wszystkich tkanek mechanizm detoksykujący $\mathrm{z}$ udziałem NADH-GDH. Jedynie w liściach 7-dniowych roślin detoksykacja $\mathrm{NH}_{4}{ }^{+}$zachodzi przy udziale NADH-GOGAT i NADPH-GOGAT. 